\title{
ANALISA PERANCANGAN SERVER VOIP (VOICE INTERNET PROTOCOL) DENGAN OPENSOURCE ASTERISK DAN VPN (VIRTUAL PRIVATE NETWORK) SEBAGAI PENGAMAN JARINGAN ANTAR CLIENT
}

\author{
Domiko Fahdi Jaya Patih*. Helmy Fitriawan. Yetti Yuniati. \\ Jurusan Teknik Elektro. Fakultas Teknik.Universitas Lampung \\ Email: "domicofahdi@yahoo.com
}

\begin{abstract}
Abstrak
Voice over Internet Protocol (VoIP) merupakan teknologi yang memanfaatkan Internet Protocol untuk menyediakan komunikasi voice secara elektronis dan real-time. Unsur pembentuk VoIP adalah User agent, Proxy, Protocol dan Coder-Decoder (CODEC). Asterisk merupakan softswicth untuk mengoperasikan proxy, yang berbasis session initiation protocol (SIP). Sistem operasi Ubuntu 10.10 sebagai server VoIP cukup fleksibel untuk mendukung kinerja paket Asterisk. Tujuan dari penelitian ini adalah membangun server VoIP berbasis Asterisk, agar dapat dikembangkan pada penelitian selanjutnya sesuai dengan kebutuhan. Metodologi penelitian yang dilakukan, secara garis besar terdiri dari dua alur, yaitu studi literatur dan percobaan. Penelitian ini dilakukan pada instalasi yang sudah dibangun jaringan internet sebelumnya. Sehingga VoIP disini difungsikan sebagai pemaksimalan jaringan internet yang sudah ada tersebut untuk menekan biaya pengeluaran kebutuhan komunikasi. Layanan yang disediakan pada penelitian ini berbentuk voice dan video dengan layanan call client to server, call client to client, video call conference, video conference.
\end{abstract}

Kata Kunci : Voice over Internet Protocol, (VoIP), Asterisk, Session Initiaton Protocol (SIP), VPN.

\begin{abstract}
Abstrack
Voice over Internet Protocol (VoIP) is a technology that utilizes the Internet Protocol to provide real-time voice communication. VoIP technology is a today telecommunication technology, where the costs of the technology infrastructure is much cheaper than the telecommunications technology that is commonly used today. Forming elements are VoIP User Agent, Proxy, Protocol and Coder-Decoder (CODEC). Asterisk is a softswicth to operate a proxy, which is based on session initiation protocol (SIP). 10.10 Ubuntu operating system as a VoIP server is flexible to support a package of performance Asterisk. The goal of this research is to build Asterisk-based VoIP server, that can be developed in further research as needed. The methodology of research conducted, is devided by two, the study of literature and experimental. The research was conducted at the installation that has been built before the Internet network. VoIP so here functioned as maximizing existing internet network is to reduce expenses communication needs. Services provided in this study form with voice and video call services client to server, client to client call, video call conferencing, video conferencing
\end{abstract}

Key Word : Voice over Internet Protocol (VoIP), Asterisk, Session Initiaton Protocol (SIP), VPN 


\section{Pendahuluan}

Perkembangan jaringan komputer yang semakin pesat memungkinkan untuk melewatkan trafik suara melalui jaringan komputer atau biasa yang disebut VoIP (Voice over Internet Protocol). Voice over Internet Protocol (juga disebut VoIP, IP Telephony, Internet telephony atau Digital Phone) adalah teknologi yang memungkinkan percakapan suara jarak jauh melalui media internet. Data suara diubah menjadi kode digital dan dialirkan melalui jaringan yang mengirimkan paket-paket data dan bukan lewat sirkuit analog telepon biasa. Definisi VoIP adalah suara yang dikirim melalui Internet Protocol (IP). Saat ini terdapat 2 teknologi utama internet telephony, yaitu teknologi $\mathrm{H} .323$ dan Session Initiation Protocol (SIP), keduanya sering digunakan[1]. Penggunaan jaringan IP memungkinkan penghematan biaya, karena tidak perlu membangun sebuah infrastruktur baru untuk komunikasi suara dan penggunaan lebar data (bandwidth) yang lebih kecil dibandingkan telepon biasa. Penggunaan teknologi VoIP yang lebih efisien akan semakin dipermudah karena dapat digabungkan dengan jaringan telepon lokal yang sudah ada. Setiap individu dapat membangun dan mengembangkan infrastrukturnya secara mandiri, dikarenakan penggunaan sistem operasi berbasis linux / open source Asterisk yang memang dikhususkan untuk menangani VoIP. Penggunaan teknologi VoIP sangat menguntungkan bagi penggunanya. Namun, penggunaan komunikasi yang murah dari sisi keamanan kurang begitu diperhatikan. Oleh karena itu keamanan ketika melakukan komunikasi suara merupakan sesuatu yang sangat penting karena menyangkut privasi penggunanya. Penggunaan VPN (Virtual Private Network) merupakan salah satu alternatif untuk mengirimkan voice, yang bersifat private atau aman, karena penggunaan koneksi yang telah terenkripsi serta penggunaan private keys, certificate, username atau password untuk melakukan authentikasi dalam membangun koneksi.

\section{Tinjauan Pustaka}

\subsection{VoIP (Voice over Internet Protocol)}

VoIP ( Voice over Internet Protocol) adalah teknologi yang mampu mengirimkan trafik suara, video dan data yang berbentuk paket secara real-time dengan jaringan Internet Protocol. VoIP memanfaatkan infrastruktur internet yang sudah ada untuk berkomunikasi seperti layaknya menggunakan telepon biasa dan tidak dikenakan biaya telepon biasa untuk berkomunikasi dengan pengguna VoIP lainnya dimana saja dan kapan saja. Teknik dasar Voice over Internet Protocol atau yang biasa dikenal dengan sebutan VoIP adalah teknologi yang memungkinkan kemampuan melakukan percakapan telepon dengan menggunakan jalur komunikasi data pada suatu jaringan (networking), sehingga teknologi ini memungkinkan komunikasi suara menggunakan jaringan berbasis IP (internet protocol) untuk dijalankan diatas infrastruktur jaringan packet network. Jaringan yang digunakan bisa berupa internet atau intranet. Teknologi ini bekerja dengan jalan mengubah suara menjadi format digital tertentu yang dapat dikirimkan melalui jaringan IP. Teknologi ini pada dasarnya mengkonversi sinyal analog (suara) ke format digital dan kemudian dikompres atau ditranslasikan ke dalam paket-paket IP yang kemudian ditransmisikan melalui jaringan internet. Standarisasi protocol komunikasi pada teknologi VoIP adalah SIP (Session Initiation Protocol) dan H.323. Gambar 1 memperlihatkan susunan stack pada internet media protocol.

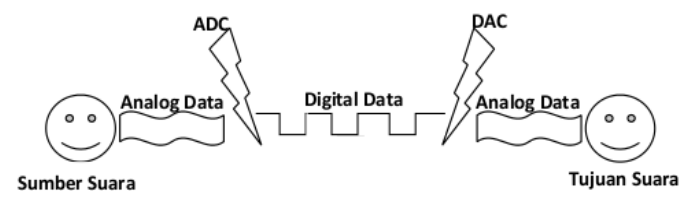

Gambar 1. Cara kerja VoIP[2]

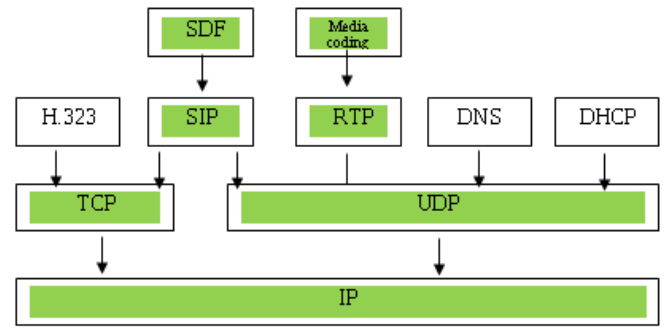

Gambar 2. Internet Multimedia Protocol stack[3]

Pada Gambar 2, protocol yang berwarna hijau merupakan protocol yang digunakan pada VoIP berbasis SIP. Dari gambar tersebut dapat dilihat bahwa VoIP menggunakan TCP dan UDP sebagai transport layer-nya.

\subsection{Parameter penentu kualitas layanan} (QoS dan MOS) VoIP

QOS didefinisikan sebagai suatu pengukuran tentang seberapa baik jaringan dan merupakan suatu usaha untuk mendefinisikan karakteristik dan sifat dari suatu layanan. QoS mengacu pada kemampuan jaringan untuk Menyediakan layanan yang lebih baik pada trafik 
jaringan tertentu melalui teknologi yang berbedabeda. Tujuan dari QoS adalah untuk memenuhi kebutuhan-kebutuhan layanan yang berbeda, yang menggunakan infrastruktur yang sama. Beberapa parameter Qos yaitu delay, jitter, throughput, dan paket loss. Delay adalah waktu yang dibutuhkan oleh satu paket dari tempat ke sumber tujuan. Jitter adalah variasi yang ditimbulkan oleh delay, terjadi karena adanya perubahan terhadap karakteristik dari suatu sinyal sehingga menyebabkan terjadinya masalah terhadap data yang dibawa oleh sinyal tersebut. Throughput adalah jumlah data persatuan waktu yang dikirim dari suatu titik jaringan ke titik jaringan yang lain Packet loss merupakan suatu parameter yang menggambarkan suatu kondisi yang menunjukkan jumlah total paket yang hilang. Kualitas sinyal yang diterima dapat diukur dengan subjektif dan objektif. Metode pengukuran subyektif yang umum dipergunakan dalam pengukuran kualitas speech coder adalah ACR (Absolute Category Rating) yang akan menghasilkan nilai MOS (Mean Opinion Score). Tes subyektif ACR meminta pengamat untuk menentukan kualitas suatu speech coder tanpa membandingkannya dengan sebuah referensi. Bila pengukuran dengan objektif maka pengukuran MOS menggunakan parameter QoS, yaitu delay, jitter, packet loss yang didapat pada saat pengukuran. Skala rating umumnya mempergunakan penilaian yaitu beruturut - turut: Exellent, Good, Fair, Poor dan Bad dengan nilai MOS (Mean Opinion Score) berturut - turut: 5, 4, 3, 2 dan 1.

\subsection{VPN (Virtual Private Network)}

Virtual Private Network atau biasa disingkat dan dikenal umum sebagai VPN atau VPN tunnel adalah sebuah mekanisme menyambungkan sebuah titik (atau biasa dengan node) pada sebuah jaringan komputer dengan titik yang lain melalui mediasi sebuah jaringan yang lain, sebuah titik dapat berupa sebuah jaringan komputer lokal (atau biasa disebut LAN) atau sebuah komputer. VPN adalah sebuah cara aman untuk mengakses local area network yang berada pada jangkauan dengan menggunakan internet atau jaringan umum lainnya untuk melakukan transmisi data paket secara pribadi dengan enkripsi perlu penerapan teknologi tertentu agar walaupun menggunakan medium yang umum, tetapi traffic (lalu lintas) antar remote-site tidak dapat disadap dengan mudah, juga tidak memungkinkan pihak lain untuk menyusupkan traffic yang tidak semestinya ke dalam remote-site. Teknologi VPN sesungguhnya adalah sebuah software yang dijalankan oleh kedua pihak yang hendak berkomunikasi melalui internet[2]. VPN adalah sebuah koneksi virtual yang bersifat privat, disebut demikian karena pada dasarnya jaringan ini tidak ada secara fisik hanya berupa jaringan virtual VPN Menghubungkan PC dengan jaringan publik atau internet namun sifatnya privat, karena bersifat privat maka tidak semua orang bisa terkoneksi ke jaringan ini dan mengaksesnya. Oleh karena itu diperlukan keamanan data dalam VPN. Dalam VPN tersebut terdapat tunnel, tunnel sendiri adalah istilah generik yang menjelaskan bahwa sebuah hubungan antar titik pada sebuah jaringan komputer dilakukan melalui semacam terowongan antar kedua titik.

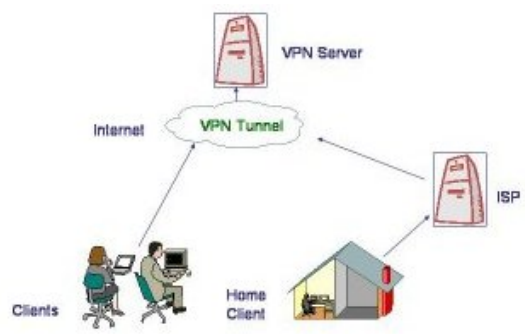

Gambar 3. Model Jaringan VPN[15]

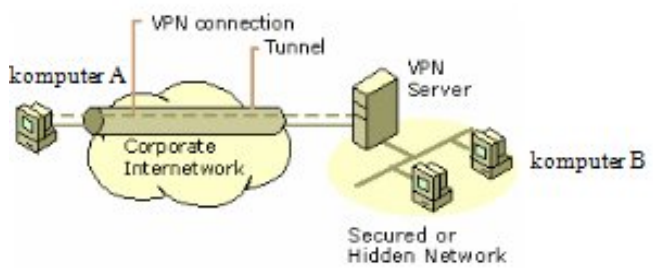

Gambar 4. Model Tunnel VPN[16]

\section{Metode Penelitain}

Metode yang digunakan pada penelitian ini adalah perancangan server VoIP, menggunakan OS Ubuntu, software Asterisk, software VPN, software VQManager, software Wireshark dan software cain and abel. Pada server VoIP ini menggunakan software Asterisk dikarenakan terbukti handal, kemudian menggunakan software VPN untuk pengaman jaringan untuk mencegah penyadapan, software VQManager dan Wireshark berfungsi untuk monitoring performa server VoIP dengan menganalisa QoS dan MOS, kemudian software Wireshark digunakan untuk mengukur throughput, dan software cain and abel untuk pengujian keamanan komunikasi. Pada penelitian ini dilakukan pengamatan terhadap parameter- 
parameter yang mempengaruhi kualitas suara seperti delay, jitter, packet loss dan throughput. Pengukuran membandingkan QoS pada komunikasi VoIP dengan menggunakan VPN dan tidak menggunakan VPN, kemudian akan dilakukan perbandingan penggunaan codec yang digunakan pada saat komunikasi dilakukan, yaitu codec alaw, gsm, ilbc, dan speex. Semua pengukuran QoS dan MOS dilakukan bersamaan. Pengukuran dilakukan dalam waktu 5 menit agar dapat terlihat nilai maksimum dan nilai minimum nilai QoS dan nilai MOS pada software pengukur.

\section{Hasil dan Pembahasan}

\subsection{Hasil pengukuran rata-rata Delay}

Pada penelitian ini salah satu parameter QoS adalah dengan pengukuran delay. Media yang digunakan untuk pengukuran QoS adalah dengan jaringan kabel RJ-45 dengan topologi delay end-toend. Delay end-to-end mengacu pada waktu yang dibutuhkan untuk paket yang akan dikirim melintasi jaringan dari sumber ke tujuan pengukuran dilakukan pada 13.00 dan 18.00. Hasil pengukuran delay ilbc adalah sebagai berikut :
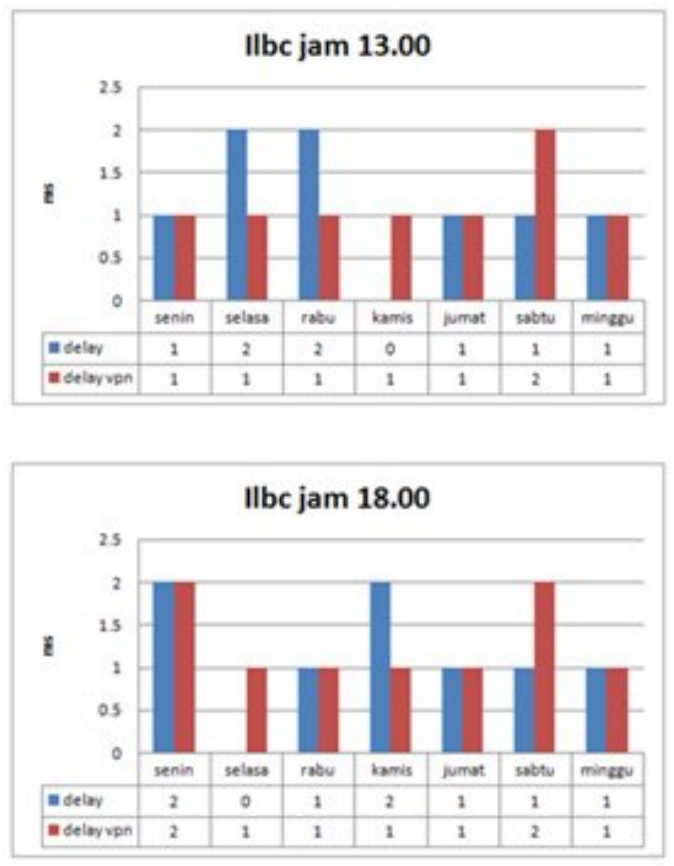

Gambar 5. Hasil pengukuran delay dengan codec $i l b c$
Pada pengukuran delay dengan keempat codec, codec ilbc yang stabil saat melakukan komunikasi.Suara yang dihasilkan terdengar jelas dengan sedikit noise dibandingkan dengan suara pada saat menggunakan codec gsm, speex, dan alaw.

\subsection{Hasil pengukuran jitter}

Parameter QoS selanjutnya adalah jitter. Jitter adalah variasi kedatangan paket yang diakibatkan oleh perubahan dalam karakteristik suatu sinyal. Variasi tersebut bisa berupa panjang antrian, waktu pengolahan data, dan juga waktu penghimpunan ulang paket-paket di akhir perjalanan jitter. Parameter jitter perlu dianalisis untuk mengetahui delay kedatangan antar satu paket dengan paket lainnya. Semakin besar jitter maka semakin perbedaan waktu antara suara asli dengan suara yang terdengar akan semakin besar. Hal itu dapat menyebabkan besarnya collision antara paket bahkan dapat menyebabkan echo cancelation. Hasil pengukan jitter ilbc adalah sebagai berikut:
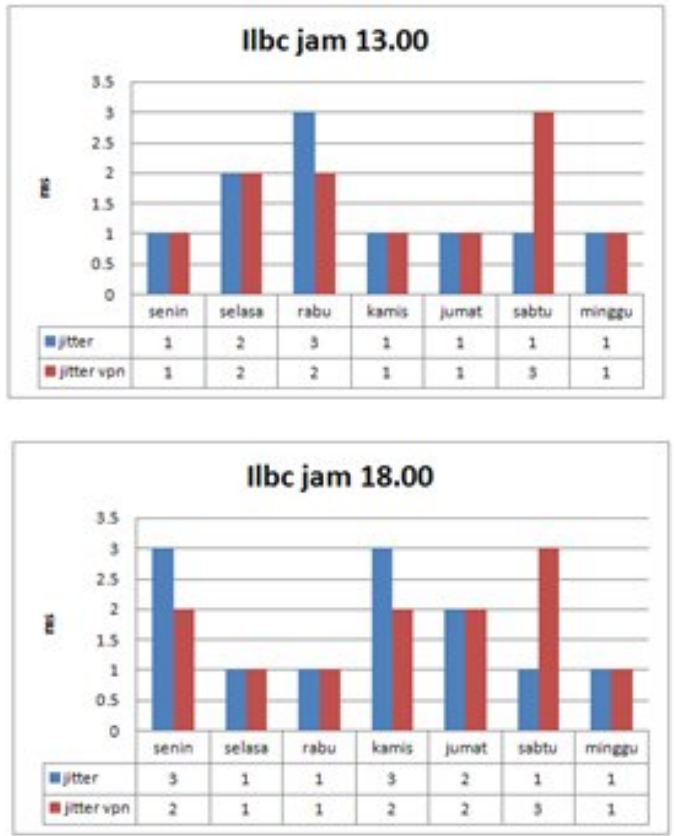

Gambar 6. Hasil pengukuran jitter dengan codec ilbc Pada penelitian ini variasi jitter yang besar sangat dipengaruhi oleh processing data voice 
dimana processing data voice dipengaruhi oleh penggunaan codec, sehingga sewaktu-waktu jitter bisa sangat besar. Nilai jitter berpengaruh ketika packet RTP yang datang akan di proses menjadi suara. Ketika nilai jitter lebih kecil dari waktu pemrosesan paket data maka sebelum paket selesai di proses paket selanjutnya telah datang untuk menunggu diproses.

\subsection{Hasil pengukuran packet loss}

Packet loss adalah jumlah paket hilang. Umumnya perangkat jaringan memiliki buffer untuk menampung data yang diterima. Jika terjadi kongesti yang cukup lama buffer akan penuh dan data baru tidak akan diterima. Packet loss (kehilangan paket data pada proses transmisi) dan desequencing merupakan masalah yang berhubungan dengan kebutuhan bandwidth, namun lebih dipengaruhi oleh stabilitas rute yang dilewati data pada jaringan, metode antrian yang efisien, pengaturan pada router, dan penggunaan kontrol terhadap kongesti (kelebihan beban data) pada jaringan. Hasil pengukuran packet loss ilbc adalah sebagai berikut:
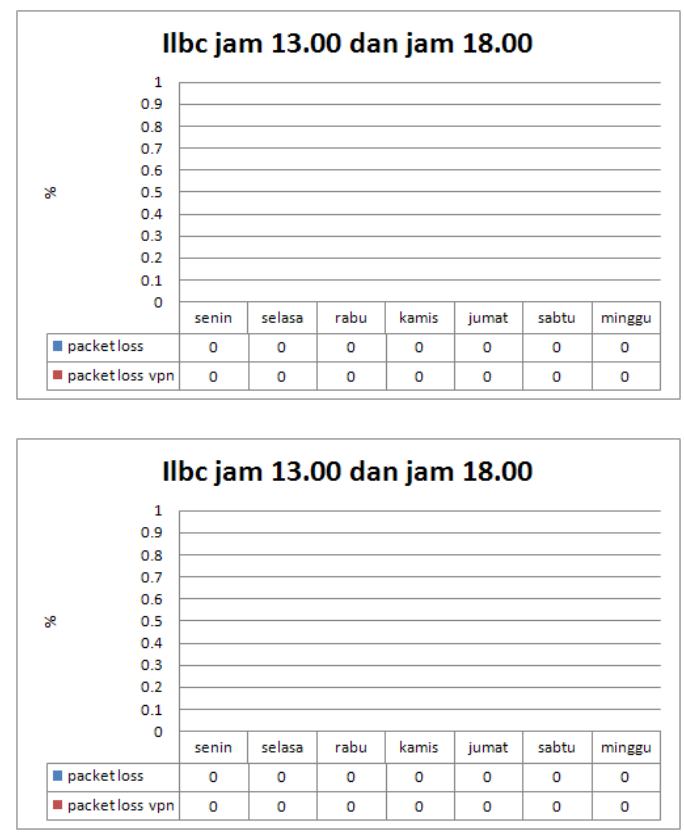

Gambar 7. Hasil pengukuran packet loss dengan codec ilbc

Pada penelitian ini packet loss data Voice dapat disebabkan pemrosesan data voice pada codec, karena pada saat codec memproses data voice, paket data voice dapat saja hilang, pada saat menggunakan codec ilbc, nilai packet loss adalah $0 \%$ sedangkan codec alaw, gsm, dan speex nilai packet loss nya sangat fluktuatif.

\subsection{Hasil pengukutan rata-rata throughput}

Throughput yaitu kecepatan (rate) transfer data efektif yang diukur dalam bps. Pada penelitian ini throughput ilbc yang terukur adalah sebagai berikut :
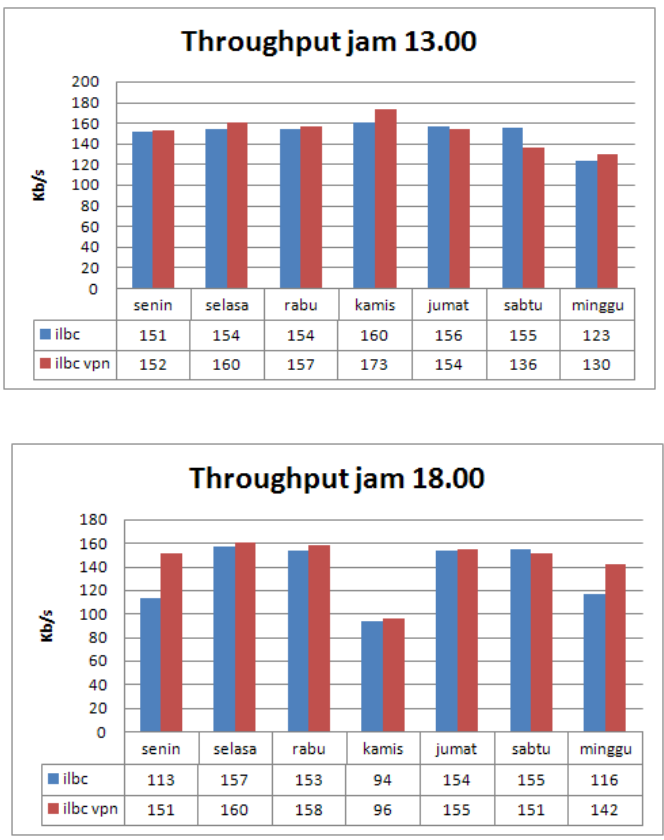

Gambar 8. Hasil pengukuran throughput dengan codec ilbc

Pada penelituan ini pengukuran throughput yang paling kecil adalah dengan menggunakan codec ilbc. Secara teori penggunaan VoIP saat menggunakan VPN membutuhkan throughput yang lebih besar namun pada saat pengukuran terkadang saat menggunakan VPN, throughput yang dihasilkan lebih kecil, hal ini dapat disebabkan pada jaringan internet dan terjadi ketidakstabilan saat pengkompresan data voice serta terjadinya packet loss data voice.

\subsection{Hasil Pengukuran MOS}

Pada penelitian ini pengukuran MOS menggunakan Software VQManager. Pada 
pengukuran MOS dilakukan bersamaan dengan pengukuran QoS. Pengukuran MOS pada VQManager mengacu pada nilai delay, jitter dan packet loss yang terukur pada software VQManager, nilai MOS didapat ketika nilai QoS sudah terukur pada software VQManager sehingga secara otomatis saat nilai QoS sudah terukur maka nilia MOS akan tampil bersamaan pada nilai QoS pada software VQManager tersebut. Rumus pengukuran MOS pada Software VQManager secara default pada software VQManager adalah pada delay > $300 \mathrm{~ms}$ maka nilai MOS adalah $<3,1$ dan jika delay $<300$ ms nilai MOS adalah > 3,6. Kemudian saat jitter $>$ $150 \mathrm{~ms}$ nilai MOS adalah < 3,1 dan jika nilai jitter < $150 \mathrm{~ms}$ nilai MOS > 3,6. Kemudian jika nilai packet loss > $30 \%$ maka nilai MOS adalah < 3,1 dan jika packet loss < $30 \%$ nilai MOS adalaha > 3,6. Nilai kualitas suara pada penelitian ini adalah sebagai berikut: 1 = Bad (Very annoying), 2 = Poor (Annoying), 3 = Fair (Slightly annoying), $4=$ Good (Perceptible but not annoying), $5=$ Exellent (Imperceptible). Hasil pengkuran MOS ilbc adalah sebagai berikut :

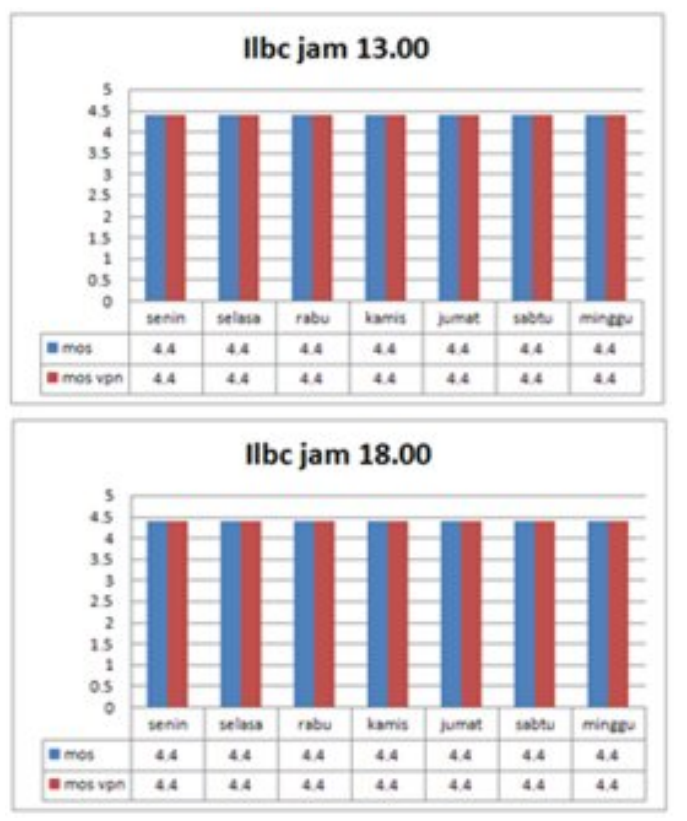

Gambar 9. Hasil pengukuran MOS pada codec ilbc

Dari hasil pengkuran, nilai MOS yang terbaik adalah dengan menggunakan codec ilbc yaitu sebesar 4,4. Pada saat dilakukan komunikasi hanya codec ilbc yang memiliki kualitas suara yang baik dibandingkan dengan codec yang lain.

\subsection{Pengujian dan Analisis Keamanan VoIP}

Pada penelitian ini setelah perancangan VoIP dibuat maka selanjutnya adalah pengujian keamanan. Pengujian keamanan pada VoIP ini dilakukan dengan cara penyadapan melalui software cain and abel, hasilnya terbukti dengan menggunakan software cain and abel saat client sedang berkomunikasi, client 3 dapat mencapture protocol SIP. Kelemahan dari komunikasi menggunakan VoIP adalah data payload tidak diproteksi sehingga ketika dikirimkan dan ditangkap maka akan dengan mudah data tersebut disadap pihak lain, ini terbukti setelah data payload VoIP ditangkap data payload dapat diputar kembali, sehingga komunikasi antara client 1 dan client 2 dapat didengar kembali. hal ini membuktikan bahwa komunikasi VoIP belum aman. Kemudian pada saat penyadapan dilakukan kembali, namun ditambahkan software VPN antara kedua client tersebut, ternyata payload tidak terdeteksi sehingga data payload tidak dapat dimainkan ulang. Hasil penelitian menunjukan bahwa komunikasi VoIP sangat mudah untuk disadap namun dengan penambahan software VPN komunikasi VoIP terbukti aman karena terdapat tunnel dan data dienkripsi sehingga pihak lain tidak dapat menyadapnya.

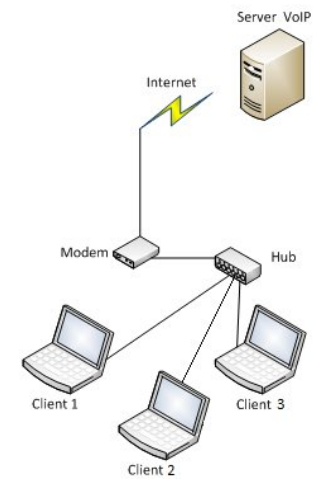

Gambar 10. Topologi penyadapan VoIP

\section{Kesimpulan}

Dari penelitian dan analisa data yang telah dilakukan maka dapat diambil beberapa kesimpulan sebagai berikut :

1. Dari keempat codec tersebut codec ilbc yang stabil untuk digunakan komunikasi

2. Pemilihan jenis codec yang tepat perlu untuk meminimalisasi nilai QoS yang terjadi pada jaringan VoIP karena pemilihan codec sangat menentukan kualitas suara. 
3. Penggunaan VPN dapat mencegah penyadapan pada VoIP

4. Terbukti bahwa dengan menggunakan VoIP biaya telekomunikasi menjadi hemat

5. Nilai throughput menggunakan VPN lebih besar dibandingkan tanpa VPN

\section{Daftar Pustaka}

1. Purbo,W.Onno \& Raharja, Anton. 2010. VoiP Cookbook Building your own Telecommunication Infrastructure. hlm 5.

2. Taufiq, Mochammad. 2008. Membuat SIP Extensions padan Linux Trixbox untuk Server VoIP (Skripsi). hlm 11.

3. Final,Muhamad Zuhdan. 2009. Rancang Bangun dan Analisis VoIP (Skripsi) Universitas Indonesia. hlm 10

4. Http://araihan.wordpress.com/2009/ 10/06/configure-l2tp-ipsec-vpnusingwindows-server-2008/

5. Http://computing.fnal.gov/vpn/ 